\title{
Development of Creative Independence of Design Students in Course of Higher Education
}

\section{Desarrollo de la independencia creativa de los estudiantes de diseño en el curso de educación superior}

\author{
Daskova Yu.V.* \\ Penza State University of Architecture and Construction, Russia \\ ORCID: https://orcid.org/0000-0003-4242-8729 \\ Poliakova Ia.V. \\ Department of Higher Education, Ministry of Education and Science, Russia \\ ORCID: https://orcid.org/0000-0003-4108-6691 \\ Vasilenko S.A. \\ Peoples' Friendship University of Russia, Russia \\ ORCID: https://orcid.org/0000-0003-0926-9092 \\ Goltseva O.S. \\ K.G. Razumovsky Moscow State University of Technologies and Management (The First Cossack University), \\ Russia \\ ORCID: https://orcid.org/0000-0003-4900-5518 \\ Belyakova T.E. \\ K.G. Razumovsky Moscow State University of Technologies and Management (The First Cossack University), \\ Russia \\ ORCID: https://orcid.org/0000-0002-7252-4247

\section{Shevalie K.N.} \\ K.G. Razumovsky Moscow State University of Technologies and Management (The First Cossack University),Russia \\ ORCID: https://orcid.org/0000-0002-4359-7965 \\ Vasilenko E.V. \\ K.G.Razumovsky Moscow State University of Technologies and Management (The First Cossack University), Russia \\ ORCID: https://orcid.org/0000-0001-5590-8823
}

Received 01-11-20 Revised 02-25-20 Accepted 06-20-20 On line 07-30-20

*Correspondence

Email: office@pguas.ru
Cite as:

Daskova, Yu.V., Poliakova, Ia.V., Vasilenko, S.A., Goltseva, O.S., Belyakova, T.E., Shevalie, K.N., \& Vasilenko, E.V. (2020). Development of Creative Independence of Design Students in Course of Higher Education. Propósitos y Representaciones, 8 (SPE2), e637. Doi: http://dx.doi.org/10.20511/pyr2020.v8nSPE2.637 


\section{Summary}

Development of Russian society puts forward new requirements for the quality of training in higher educational institutions. It is necessary for a short period of training in the higher educational institution not only to transfer to student's important professional knowledge and skills, but also to form the ability and willingness to use them creatively. This issue is especially challenging when preparing design students. Today, a promising, popular and dynamically developing profession of designer is in demand in almost all areas of life. The increased demand for individuality in the design of living space, from the planning and design of the interior or exterior to the most insignificant things, can only be satisfied by a designer who has the ability to combine, improvise and find breakthrough ideas. Therefore, there is a crucial issue of the search for teaching aids that allow students to be prepared to find the solutions of professional tasks with creative independence. The professional activity of a designer is determined by the objects and tasks, which require creative abilities, spatial visual thinking, knowledge of the graphic language for visualization of informarion. The design project is created by man and for man. This determines the importance of solving sociocultural issues, as well as taking into account the characteristics of human perception in the design process. It requires knowledge of the natural sciences, engineering and humanities, various types of arts, architecture, literature and even music. Thus, the intra-systemic and inter-systemic connections required for the implementation of designprohects, make it more intelligent and human oriented.

Keywords: Design Project; Design Activities; Creativity; Creative Independence; Design Process

\section{Resumen}

El desarrollo de la sociedad rusa plantea nuevos requisitos para la calidad de la formación en las instituciones de educación superior. Es necesario durante un corto período de capacitación en la institución de educación superior no solo transferir a los estudiantes conocimientos y habilidades profesionales importantes, sino también formar la capacidad y la voluntad de usarlos creativamente. Este problema es especialmente desafiante cuando se preparan estudiantes de diseño. Hoy en día, se demanda una profesión de diseñador prometedora, popular y en desarrollo dinámico en casi todas las áreas de la vida. La mayor demanda de individualidad en el diseño del espacio habitable, desde la planificación y el diseño del interior o exterior hasta las cosas más insignificantes, solo puede ser satisfecha por un diseñador que tenga la capacidad de combinar, improvisar y encontrar ideas innovadoras. Por lo tanto, existe un tema crucial en la búsqueda de material didáctico que permita a los estudiantes estar preparados para encontrar las soluciones de las tareas profesionales con independencia creativa. La actividad profesional de un diseñador está determinada por los objetos y tareas, que requieren habilidades creativas, pensamiento visual espacial, conocimiento del lenguaje gráfico para la visualización de información. El proyecto de diseño es creado por el hombre y para el hombre. Esto determina la importancia de resolver problemas socioculturales, así como tener en cuenta las características de la percepción humana en el proceso de diseño. Requiere conocimiento de las ciencias naturales, ingeniería y humanidades, varios tipos de artes, arquitectura, literatura e incluso música. Por lo tanto, las conexiones intra-sistémicas e inter-sistémicas requeridas para la implementación de los proyectos de diseño, lo hacen más inteligente y orientado al ser humano.

Palabras clave: Proyecto de diseño; Actividades de diseño; Creatividad; Independencia creativa; Proceso de diseño

\section{Introduction}

The relevance of the creative independence for design students is determined by social and economic changes in the life of society, as well as the importance of skills and mindset of creative independence for a professional designer (G.B. Minervin, V.T. Shimko, A.V. Efimov, etc.). The professional activity of designer is revealed through the design of a new original individual object, 
which implies such professional qualities as the ability to think creatively, navigate new professional trends, perceive a large flow of diverse information, analyze and synthesize it for further use in work, possess readiness and ability to fast learning, to be aimed at self-realization in various areas of design activity (Rosensson, 2003). In our knowledge society, it is more and more important to encourage students to develop their abilities to reason and think creatively. The notion of the knowledge society is widely discussed in the literature, with many ideas about knowledge and education emerging in recent years. For example, exploring theoretical underpinnings of the concept, Hammersh $\varnothing j$ (2006) strongly contends that the knowledge society is an economic concept based on the idea that the primary focus of production has shifted from industry to knowledge. This production is of specifically creative knowledge, as indicated by a contemporary discursive emphasis on both "creativity and innovation". From the literature, the following question arises: when the capacity to be creative is in demand, what is it then important for artists, thinkers and students in higher education to learn? Laurillard (2002) has argued that universities have responded to the knowledge society's need for more graduates, mainly taking the form of improved access policy and strategies to programmes of study. Although the notion of a knowledge society is contentious, its currency in the 21st century highlights the need for the development and facilitation of student creativity. The first part of the chapter prompts readers to think about creativity - their students' and their own - in new ways. Indeed, encouraging educators to think about creativity is critical for developing students' creativity. The second part of the chapter addresses the question of how to develop student creativity by discussing practical strategies for encouraging it through designing curricula for creativity, facilitating learning for creativity and devising assessment strategies that promote creativity. The implications of this for the professional development of teachers in higher education are discussed. The chapter also includes in an appendix a list of references and resources aimed at prompting readers to play further with their understanding and practice of encouraging student creativity. Exploring the Nature of Creativity here we offer some ideas about student creativity, drawing on:

- philosophical and theoretical understandings of creativity

- starting points for creativity

- the four interweaving elements of creativity

- perspectives on the outcomes of creativity.

Philosophical and Theoretical Understandings Brockling) presents an illuminating fourdimensional philosophical view of creativity. It illuminates the argument on creativity in this chapter as it is propagating the need for creativity, freedom and self-determination to harmonise, aspects that teachers can support in their own students. It is: firstly, something that everyone has - an anthropological capacity; second, something one ought to have - a binding norm; third, something one can never have enough of - a telos without closure; fourth, something that can be intensified through methodological instruction and exercise - a learnable competence.

Creative independence determines the methods and techniques of design, allows improvising in the course of solving design problems. Important feature of design is the integration of organizational, managerial, information-technological and art-designing activities aimed at creating aesthetic, original, convenient and at the same time practical subject-spatial environment for human life (Altshuller, 1989; Ilyin, 2009).

The need to develop creative independence among design students is also confirmed by the real requirements of employers. From the point of view of employers, a designer should have creative potential, flexible approach to work, be prepared and capable of self-realization. The most common requirement of recruiting agencies is creative thinking, creative approach to work or task, etc (Torshina, 2002). Employers understand that designer should be responsible for the project, and this requires creative independence. It is the designer who should be able to create aesthetically functional, cost-effective and at the same time original product. Modern 
requirements of employers and consumers necessitate the changes in professional training, associated with the search for the system that promotes creative independence among design students (Badakhova, 2017; Komarova, 2018; Sergeeva \& Trubakova, 2017; Schwarzkopf, 2018; Badakhova, 2017).

The Four Elements of Creativity The operational definition of creativity for this chapter is provided by Robinson, who characterises creativity as having four main elements:

- the medium

- expertise in or mastery of the medium

- the need to play and take risks

- the need for critical judgement. Each of these elements gives rise to important considerations for learning and teaching. For example, it is important to consider media for creativity in order to answer the following types of questions about learning and teaching strategy:

- What are the right media for individual students in relation to their interests, talents and preferences?

- As an educator, how can I best develop creativity in students by allowing or encouraging them to find the right medium or combination of media?

- What are my critical reflections on the media I currently use in my teaching? We should be aiming not only to help students explore media for creativity, but also to achieve expertise in or mastery of certain media. Therefore, we might consider the following questions:

- What opportunities do we provide as educators for our students to reach high skills levels in the use of a variety of media?

- Do we teach academic writing, creative writing, visual literacy, drawing or whatever skills are relevant to our students to develop their creativity?

- How do we foster both the development of learning skills and imagination? As we answer these questions, we might remember that creativity "is not only a matter of control: it's about speculating, exploring new horizons, and using imagination"

- Some asserts that play has replaced work as the dominant mode of the 21 st century for generating meaning. In higher education, we can encourage students to play with the ideas and interrelationship between concepts by asking ourselves the following questions:

- Do we give students freedom enough to play?

- Are we, as educators, enthusiastic and playful about our subjects?

- How do we encourage students to combine creative thinking with critical thinking, brainstorming with judgements and exploration with discipline in ways that will enhance their creativity?

How do we stimulate students to articulate the questions they want to explore rather than simply transmitting knowledge to them? By dialoguing with these questions, we can find concrete ways to encourage students to engage in the creativity of playfully combining things that they have not previously combined together. The Outcomes of Creativity is also characterized by the nature of its outcomes. Thus, Robinson defines creativity as "imaginative processes with outcomes that are original and of value". It is important that in our work of developing creativity we both widen and revitalize our notion of originality. Originality is not only about producing something new but also about combining old elements in new ways or applying old ideas to new contexts in order to work on a problem, advance a particular field and to add to the storehouse of knowledge and the repertoires of professional and artistic practices. Murray and Moore (2006, p. $31)$ note that creative people are "more likely to think in boundary less ways about a topic, and are happy to 'borrow' important notions from fields of enquiry other than their own". The outcomes of creativity are personal and/or economic, but can also be spiritual, social, environmental and political. 


\section{Literature Review}

The results of scientific research indicate the increased interest in the problem and prove the advisability of considering creative independence as the leading factor in improving the quality of professional training of designers. Researchers distinguish the following qualities of creative independence significant for designer: the need for state-of-the-art knowledge, understanding the ways of obtaining it and the ability to apply it in different conditions (V.V. Drozina, A.A. Shamsieva, etc.); critical approach to the results of their own activities and the activities of other people (A.V. Kachalov); the ability to express a personal vision, generate several possible solutions and make the selection of the optimal ones (L.B. Surina and others); need and ability for improvisation and orientation toward self-expression (N.Yu. Ermilova and others).

If creativity is so important, how do we facilitate it? There have been extensive and comprehensive reviews of the large literature's bases within creativity, teaching and learning by Stein (1988) and Fryer (2003), among others. There has, however, been a lack of critical engagement with the question of introducing creativity to the higher educational system. Indeed, Gardner (1982) notes that earlier studies of learning and development had mostly neglected creativity. Recently, this gap has been addressed by Jackson, Oliver, Shaw \& Wisdom (2006), who focus on the role of creativity in higher education. Csikszentmihalyi (2006) believes that if young people become involved with what they enjoy, the foundations for creativity will be in place. It follows therefore that teachers must model the joy of learning themselves, and be able to spark it in their students. Similarly, pedagogy should be focused on arousing student imagination and engagement. Since the late 1990s, several studies have identified common themes in what students and teachers say about how best to facilitate student creativity in higher education. For example, Cropley (2001) suggests that surveys have shown that in theory at least, teachers overwhelmingly support creativity as something that should be fostered in the classroom. Moreover, teachers who successfully facilitate creativity are likely to be those who encourage independent learning, take student questions seriously, promote self-evaluation, reward courage as much as correctness, and who have a cooperative, socially integrative teaching style. Research by Oliver et al (2006) on students' experiences of creativity in a broad spread of subject disciplines points to specific teaching techniques that students consider to be creative. These include roleplaying, debates and posters for class presentations. Some quite conventional forms of teaching are also nominated as creative, specifically dialogic teaching with discussions that concentrate on students' current understanding or beliefs. One-to-one tutorials are highlighted as especially helpful to students, as are providing encouragement, giving examples or offering feedback. Teachers should note that it is how these techniques are used, rather than the mere inclusion of them within our repertoire of techniques, that is the key to success. A study by Fryer (2006) identifies several teaching techniques for facilitating creativity: heuristic strategies i.e. problembased learning (Barrett 2005); game-based learning that utilises challenging problems; real-life scenarios; practical exercises; and groupwork. As in Oliver et al (2006), Fryer's work shows that positive teacher attitudes and supportive factors such as the relationship between tutor and students are also significant in facilitating a creative learning environment. Teaching specific creative thinking tools in a way that is embedded into the discipline is important to provide the foundations for students to work creatively (Baille 2003). There are several thinking tools such as the six thinking hats technique that can be used to stimulate creativity among students (de Bono, 1999; Baille, 2003). These techniques have been proven to stimulate creativity in both education and work contexts.

Analysis of the problem under study from the point of view of pedagogy (B.G. Ananyev, B.D.Bogoyavlenskaya, A. Disterweg, M.P. Druzhinina, E.A. Klimova, A.N. Leontiev, L.B. Ermolaeva-Tomina and others) and psychology (Ya.A. Ponomarev, L.S. Vygotsky, A.M. Matyushkina K.A. Abulkhanova-Slavskaya, S.L. Rubinshtein, J. Guilford, A.T. Shumilin, etc.), 
allowed to consider creativity as a methodological basis for the development of creative independence. Creativity appreciated by D.B. Bogoyavlenskaya, L.B. Ermolaeva-Tomina as the highest stage of manifestation of any activity, if it is characterized by the ability of a person to see and formulate a problem, make accurate forecast, apply existing knowledge to new conditions, find original ways to solve the problem. Creativity is the need and desire to achieve an original result (P.I. Pidkasisty, V. B. Bondarevsky, M. G. Garunov, V. V. Drozina, etc.). Researchers, turning to the basis of creative independence, identify cognitive (A.A. Kuleshova, O.A. Chelyadinova, N.Yu. Ermilova, etc.), practical (A.A. Kuleshova, V.V. Drozina, etc.), motivational-value (I.B. Karnaukhova, O.A. Chelyadinova, L.Yu. Kruglova, etc.) components of its structure. Invariably important is the creative component, characterized by the ability and need for the manifestation of individuality, originality, creativity (N.Yu. Ermilova, A.A. Kuleshov, I. B. Karnaukhov and others) (Badakhova, 2017; Gadzhieva, 2018; Osipova, 2018; Borisova, 2018; Borovikova, 2017; Larskikh \& Larina, 2017; Yazovskikh, 2018; Gadzaov \& Dzerzhinskaya, 2018; Gasanova et al., 2017; Gnatyuk \& Pekert, 2018; Kryuchkova, 2018; Kuznetsov et al., 2018).

At the same time, some aspects of creative independence remain, for the time being, insufficiently studied. The content analysis of professional disciplines, defined by the Federal Educational Standard of Design showed that this block of disciplines reveals the professional issues in accordance with the art-design, organizational, managerial and informationtechnological types of professional activity. The disciplines of professional block allow students and teachers to experiment and generate non-standard ideas, to show creative independence in applying the acquired knowledge. This should be facilitated by specially selected educational content, methods and conditions (Daskova, 2016). The following aspects of the development and improvement of methods for stimulating the independence and creativity of students are essential:

- general issues of progressive learning technologies (M.M. Novik, A.M. Smolkin, V.N. Kruglikov, N.V. Borisov, etc.);

- business role-playing games in the educational process (Yu.A. Arutyunov, G.P. Shchedrovitsky, etc.);

- activating the creative thinking of student architects by the method of searching for technical solutions (G.O. Bush, S.K. Sarkisov, E.V. Sidorenko, etc.);

- activization of students by means of creative search tasks (S.A. Novoselov, M.M. Zinovkin, A.A.Simonov and others).

Of significant importance for our research are the works that determine certain aspects of creative independence of design students (L.M. Takhbatulina, V.G. Gladkikh, Yu.V. Veselova, O.V. Arefieva, M.E. Elochkin, R.F. Mukhutdinov, S.M. Murzin, I.B. Troshin, O.S. Shkil, etc.).

\section{Proposed Methodology}

Analysis of the existing experience in the field of creative independence made it possible to identify the most significant provisions for our study:

firstly, creative independence is not only the system of certain knowledge and skills, but also the ability to think independently, find innovative solutions to challenging tasks, to anticipate final results of one's activities (Sumar I.K. et al.);

secondly, creative independence is the ability to transfer knowledge and skills to a new situation, the vision of a new function of an object as opposed to the traditional one, the construction of a fundamentally new solution different from known ones, etc. (Drozina V.V., Shamsieva A.A. et al.);

thirdly, creative independence is an integral quality of a person characterized by the ability to independently set the goal of educational and professional activity and to predict its creative 
solution, to update the necessary knowledge and ways to achieve it, to plan and adjust actions, to correlate the result with the goal (Shamsieva A. A., Kachalov A.V. et al.).

Most researchers note that creativity and independence complement and mutually determine each other. According to V.V. Drozina, creativity in this case manifests itself as a student's individual style coinciding with his/her abilities for this subject, aimed at selfdeveloping (Chelyadinova, 2012).

Based on the content analysis and the experience, we identified the following key aspects for determining the notion of creative independence:

- activity showing signs of creativity;

- the need to find unconventional ways to solve the problem, which implies the ability to improvise and focus on self-expression.

Theoretical and experimental research works of P.I. Pidkasisty, V.B. Bondarevsky, N. V. Bordovskaya, M. G. Garunov, P. Kravchuk, V. I. Orlov and others showed possible ways to substantiate the structure and components of creative independence. A more precise definition of the creative independence of a designer is formulated taking into account the analysis of professional design activities (Klimov, 2005).

The key feature of professional design is the integration of organizational, managerial, information-technological and art-designing types of activities aimed at the formation of aesthetic subject-spatial environment for human life. The task of design is the creation of a project. It is determined by objects and tasks that require the integration of knowledge from various fields sociology, cultural studies, history, art history, technology, engineering design, materials science. A design project is a product using graphic language as a special type of information visualization, requiring spatial and artistic thinking and characterized by humanistic orientation, taking into account universal values and modern visions (Andreev, 1988). Design features are reflected in the Federal Educational Standards of the new generation, where the following types of professional activities for design students are formulated and described.

Art and design activity are the ability to compose conceptual ideas of artistic image, mastering the skills of graphic visualization of an idea, taking into account modern environmental values, choose optimal solutions, directing them to the generation of modern ideas.

Organizational and managerial activities include the ability to organize and manage student's own work and the work of the performing team, building successful professional communication relationships with co-workers and customers.

Information and technological activity imply forecasting the impact of the created product on people, the ability to determine constructive and technological solutions, identify methods of presentation and protection of projects.

The listed activities of designer are closely interconnected and interpenetrated. They require updating existing knowledge, skills to acquire new knowledge, make selection and apply it creatively, originally, individually, depending on the design conditions (Ponomarev, 1976).

Considering the peculiarities of design activity, we determined the creative independence of design students as a focused educational and practical activity, characterized by creativity, involving the ability to improvise and combine, the desire to create an original object. We have identified the following components of the structure of creative independence (Daskova, 2011): value-motivational; design and activity and cognitive. 
The value-motivational component includes the desire and abilities to combine and improvise, create breakthrough ideas. The basis of the cognitive component is knowledge about design, its methods and technologies, about heuristic methods for generating new ideas. The design and activity component includes the ability to organize and carry out project activities from the search stage, analysis of the subject-spatial environment and creative search to its implementation; the ability to find and apply innovative methods and technologies; the ability to analyze, adjust and evaluate the results, knowledge of creative methods for presenting the results of the work done. Thus, the structure of creative independence of design students is represented by a system of interconnected components based on general cultural and professional knowledge, skills and values. Studying the current state of the theory and practice convinces that the field of creative independence among design students has not yet been clearly studied. Most often, we have encountered research works related to certain narrow aspects of creative independence, such as creativity, independence, creative individuality. In contrast, creative independence is quite new for educational science and is reflected in a much smaller number of works (V. Ya. Ponomarev, M.G. Garunov, D. B. Bogoyavlenskaya, P. A. Gorsky, V. I. Andreeva, V. B. Bondarevsky, etc.).

\section{Result Analysis}

The research results presented in the works of R.F. Makhutdinov, N.N. Nechaev, L.M. Tukhbatullina and others aimed us at the search for pedagogical tools that activate and develop internal motives of educational and creative activity. We took into account that the development of creative independence of design students takes place gradually in stages under the conditions of regular independent educational and creative activities of students. The stages of development of creative independence were considered from the perspective of a gradual reduction in the measure of teaching assistance to the student in the implementation of educational and creative activities, the scope of knowledge application, the transition from reproductive tasks to creative ones. We identified three stages in the development of creative independence (Daskova, 2016):

1. Reproductive stage. Student's activities are carried out under the guidance of a teacher at all stages of educational design and are characterized by unstable attitude to project activities. Student does not have systematic knowledge, and shows no willingness to use it in specific situations. The goals and objectives of educational and creative activities are defined in general terms.

2. Reconstructive-variable stage. Student's activities are characterized by creative independence with little guidance from the teacher. The teacher corrects, directs, advises, helps to draw up a plan and ways to complete the work. Unlike the first stage, the student takes the initiative, the desire and has certain opportunities to complete part of the project on his/her own. There are elements of the search for new solutions in standard design conditions. In the personality of student, a tendency to a steady creative attitude towards project activities is manifested.

3. Stage of creative independence. In the students' educational activities a high level of anticipation is observed. The student can complete the project independently, relying on own knowledge and skills, he /she sets the goal, formulates the educational problem, and plans the steps for solving it. The teacher acts as a coordinator of actions, helps the student in finding ways of self-control. The student's personality is characterized by a positive emotional orientation, steady search for new methods of project activity.

In the course of the theoretical analysis, it was found that the level of the creative independence of design students is adequately reflected via the following criteria:

- motivational (the presence of formed motives), including reflection of one's own value and motivation system, creative attitude and interest in a future profession, orientation towards achieving high results in it; 
- cognitive (knowledge of the creative activity methods) is manifested in the ability to apply various methods of activating creative thinking and imagination, in their flexible and constructive use;

- activity (knowledge of the forms and methods of independent activity) is manifested in the ability to organize, plan, adjust and critically evaluate educational and creative activities (Burns, 1986).

- In other words, the level of creative independence is determined by the organic unity of components:

- incentive, i.e. motivational (motives of creative independent activity),

- content, i.e. cognitive (professional knowledge of creative methods).

- technical, i.e. activity (forms and methods of independent activity).

Next, we chose diagnostic tools that allow quantitatively and qualitatively evaluate each criterion for the development of creative independence (Table 1).

Table 1.

Methods of studying the criteria for the development of creative independence

\begin{tabular}{|c|c|c|}
\hline $\begin{array}{l}\text { Components of creative } \\
\text { independence }\end{array}$ & $\begin{array}{l}\text { Criteria for the level of } \\
\text { creative independence }\end{array}$ & Diagnostic tools \\
\hline $\begin{array}{c}\text { Evaluative and } \\
\text { motivational }\end{array}$ & motivational & $\begin{array}{l}\text { - Modification technique for } \\
\text { learning motivation activities of } \\
\text { N.Ts. Badmaeva } \\
\text { - questionnaire for defining } \\
\text { Students need for creative } \\
\text { independence } \\
\text { - Observations, conversations, } \\
\text { interviewing, training discussions, } \\
\text { study of activity products }\end{array}$ \\
\hline Cognitive & Cognitive & $\begin{array}{l}\text { - Supervision of students in the } \\
\text { process of creative assignment } \\
\text { - Method of studying products } \\
\text { (Clauses, sketching, prototyping) }\end{array}$ \\
\hline Project and action & Action & $\begin{array}{l}\text { - Johnson's adapted by } \\
\text { E.E. Tunic } \\
\text { - Method of studying activity } \\
\text { products (presentation, portfolio) } \\
\text { - Trainings }\end{array}$ \\
\hline
\end{tabular}

During the indicative experiment, a number of shortcomings were identified that impeded the effective formation of creative independence. It was noted that some design students showed no interest in creativity in educational project activities. Often students were not able to generate a large number of ideas for solving tasks that require coming up with something new, sometimes passive position of students was observed. Such inaction slowed creative thinking and, as a result, required additional time to complete the task. Another urgent problem is the lack of knowledge and inability to apply knowledge already gained in other disciplines. A student survey and pedagogical observation showed that the problems identified are related to the fact that educational tasks are mainly focused on solving narrow goals and do not actualize interdisciplinary knowledge of students. There is no connection between the educational process and real project tasks. The problem was in the approach to assessing the student's work process and the results. In most cases, the traditional approach was used to evaluate the result on a five- 
point scale without taking into account the creative activities. As the result, in the end of the work, students often acted rashly, inconsistently and messy. Often they did not try to think over the sequence of work, they were afraid to make a mistake, avoiding experiments and improvisations. The analysis of the answers to the authors' questionnaire "Development of creative independence among design students" necessitated this research. The importance of creative independence for the professional work of designer was positively evaluated by all students. At the indicative stage of the experiment, the initial level of creative independence in the control and experimental groups was revealed. The data for each group are presented in Table 2.

Table 2.

Levels of creative independence of design students at the indicative experimental stage (Experimental Group and Control Group)

\begin{tabular}{|c|c|c|c|c|c|c|}
\hline \multirow[t]{4}{*}{ Levels } & \multicolumn{6}{|c|}{ Criteria } \\
\hline & \multicolumn{2}{|c|}{ Cornitive } & \multicolumn{2}{|c|}{ Action } & \multicolumn{2}{|c|}{ Motivational } \\
\hline & $\begin{array}{c}\% / \\
\text { number } \\
\text { of } \\
\text { students }\end{array}$ & $\begin{array}{l}\% / \text { number } \\
\text { of students }\end{array}$ & $\begin{array}{c}\% / \text { number } \\
\text { of students } \\
\text { o }\end{array}$ & $\begin{array}{l}\% / \text { number } \\
\text { of students }\end{array}$ & $\begin{array}{l}\% / \text { number } \\
\text { of students }\end{array}$ & $\begin{array}{l}\% / \text { number } \\
\text { of students }\end{array}$ \\
\hline & $\begin{array}{l}\text { Experi } \\
\text { mental } \\
\text { Group }\end{array}$ & $\begin{array}{l}\text { Control } \\
\text { Group }\end{array}$ & $\begin{array}{c}\text { Experimen } \\
\text { tal Group }\end{array}$ & $\begin{array}{l}\text { Control } \\
\text { Group }\end{array}$ & $\begin{array}{c}\text { Experiment } \\
\text { al Group) }\end{array}$ & $\begin{array}{l}\text { Control } \\
\text { Group }\end{array}$ \\
\hline Low & $31 / 13$ & $30 / 13$ & $69 / 30$ & $70 / 30$ & $55 / 24$ & $67 / 29$ \\
\hline Medium & $58 / 25$ & $60 / 26$ & $21,5 / 9$ & $22 / 9$ & 3515 & $25 / 11$ \\
\hline High & $11 / 5$ & $10 / 4$ & $9,5 / 4$ & $8 / 3$ & $10 / 4$ & $8 / 3$ \\
\hline
\end{tabular}

The results of the indicative experiment revealed a slight difference in the indications of the cognitive (the average level prevails 58\%/60\%), action (the low level prevails 69\%/70\%) and motivational criteria. Particularly noteworthy is the revealed low level of motivational criterion $(67 \%$ and $55 \%)$ in both groups. Motivational criterion serves as a starting point for the recognition of professional affiliation and is the beginning of the manifestation of creative style, conscious active development of the designer.

\section{Conclusion}

The development of creative independence among design students is a prerequisite for improving the quality of training. It is provided by the use of pedagogical tools to enhance the independent activities of students, contributing to the disclosure of creative potential and the manifestation of individuality, as well as developing internal motives for educational and creative activities (Badakhova, 2017). Relying on the independent self-determined activity of students in the educational process, the teacher can contribute to their motivation and desire for creativity. The predicted result is achieved on the basis of sequentially complicated creative tasks, professionallyoriented tasks, interdisciplinary connections, the use of methods of activating creative independence, as well as methods of stimulating and motivating educational and creative activities. Solving the problem of creative independence for design students, we relied on our experience, given the innovative changes in Russian education and the increased demands of employers for specialists in the field of design (Lomakina \& Sergeeva, 2008). This study makes a certain contribution to the development of vocational education in the period of increasing complexity of requirements for graduates. However, we are aware that not all assigned tasks are equally solved. The issues of adaptation of the proposed system and the study of its application in the context of teaching other blocks of disciplines in a higher or secondary specialized institution, the development of integrative courses combining the disciplines of the humanitarian, general artistic and professional cycles need further research. 


\section{References}

Altshuller, G.S. (1989). Life strategy of a creative person. In: Faces of creativity/G.S. Altshuller, I. M. Vertkin. Sverdlovsk: Middle Ural Book Publishing House, 129 p.

Andreev, V.I. (1988). Dialectics of education and self-education of a creative person. Kazan: Publishing house of KSU, 238 p.

Badakhova, I.T. (2017). Formation of Professionally Significant Qualities of Future Managers in the Training Process Forming. Modern Scientist, 7, $81-84$.

Borisova, M.V., Musokhranov, A.Yu., \& Sidorova, N.A. (2018). Use of fitness directions elements on physical education classes and their psychomatic impact on students of the special medical group. Modern Scientist, 1, 6 - 9 .

Borovikova T.V. (2017). Methodological bases of formation of the intellectual potential of territories in the conditions of innovative economy. Modern Economy Success, 6, $46-$ 49.

Burns R. (1986). Development of self-concept and education. Moscow: Progress. 317 p.

Chelyadinova O.A. (2012). Formation of creative independence of students in a culture-like environment of a pedagogical university: abstract of a thesis. Cand. Ped. Sciences. 13.00.08, Shuya.

Daskova Yu.V. (2011). On the problem of enhancing the creative independence of design students. Bulletin of the Federal State Educational Institution of Higher Professional Education "Moscow State Agro-engineering University named after V.P. Goryachkina". Theory and methodology of vocational education, 3(48). Pp.147-151.

Daskova Yu.V. (2016). Creative independence of design students: essence and structure. Scientific Review: Humanitarian Research, 12, 98-102.

Gadzaov A.F., \& Dzerzhinskaya M.R. (2018). Mathematical methods of analysis of the periodic components of economic processes. Modern Economy Success, $1,14-18$.

Gadzhieva U.B. (2018). Socialization of personality as a factor in the mental, intellectual and spiritual-moral development. International Journal of Medicine and Psychology, 1(2), 17 -20 .

Gasanova, P.G., Daudova, D.M., Kabieva, R.A., \& Tsahaeva, A.A. (2017). Moral qualities of businessmen in public con-sciousness. Modern Scientist, 1(1), $209-211$.

Gnatyuk, S.N., \& Pekert, N.A. (2018). Education as a factor of sustainable development of agriculture. Russian Economic Bulletin, 1(3),18 - 27.

Ilyin, E. P. (2009). Psychology of creativity, creativity, talent. Saint Petersburg: Peter, 448 p.

Klimov, E.A. (2005). Psychology of professional self-determination: textbook. A manual for students of higher pedagogical institutions, 2nd ed., Revised. Moscow: Publishing Center "Academy", 304 p.

Komarova, S.L. (2018). The assessment of the consumer basket for the analysis of the region competitiveness. Russian Economic Bulletin, 1(2), 19 - 25.

Kryuchkova, K.S. (2018) Modular training of future teachers with the use of information technologies in the conditions of virtual academic mobility. Modern Humanities Success, 4, $9-14$.

Kuznetsov, A.A., Ignatyeva, T.A., \& Kuznetsov, A.O. (2018). Strategy and key elements of competitiveness. Modern Economy Success, 1, 25 - 29.

Larskikh, Z.P., \& Larina, I.B. (2017). Holding an elective course with the purpose of formation communicative culture of a future bachelor. Modern Scientist, 6, $168-171$.

Lomakina, T.Yu., \& Sergeeva, M.G. (2008). Pedagogical technologies in professional educational institutions. Moscow: Academia, 288 p.

Osipova, M.B. (2018). Tendencies of development of educational practice of the modern educational organizations. Modern Humanities Success, 1, 10 - 13.

Ponomarev, Y.A. (1976). Psychology of creativity and pedagogy. Moscow: Pedagogy, 280 p. 
Rosensson, I.A. (2003). Fundamentals of design theory: a textbook for universities. Peter, 2003, $217 \mathrm{p}$.

Schwarzkopf, N.V. (2018). Improving the use of data mining technology as a way of reducing credit risk. Russian Economic Bulletin, 1(1), 10 - 18.

Sergeeva, M.G., \& Trubakova, D.I. (2017). Teacher's Reflection Formation as Factor of Effectiveness Children's Social Intelligence Forming. Modern Scientist, 7, 62 - 64.

Shimko, V.T. (2004). Fundamentals of design and environmental design: textbook. Moscow: Publishing house "Architecture-S", $160 \mathrm{p}$.

Torshina, I. B. (2002). Formation of professional competence of a future costume designer (Based on the material of art designing school of clothes): Dissertation ... Cand. Ped. Sciences: 13.00.08. Kursk, 246 p.

Yazovskikh, E.V. (2018). Employment of graduates as one of the efficient activity indicators of the higher educational establishment, ural federal university is taken as an example processes. Modern Economy Success, 1, 33 - 37. 